date compounds by both hydrogen and aluminothermic reduction. It also serves to point out aqueous processing conditions that can be employed for recovering molybdenum in the form of ferrimolybdate compounds from a low grade molybdenite concentrate.
1. O. K. Mehra, D. K. Bose, and C. K. Gupta: Trans. IIM, April 1973, pp. 1-7.

2. N. F. Neumann and P. B. Crimes: U.S. Patent No. $3,865,573$, 1975.

3. E. V. Tkachenko, A. V. Guryev, and B. V. Mikhaylov: Russ. Metall., 1976, vol. 5, p. 21.

Correction to Metall. Trans. B, 1981, vol. 12B

The Thermodynamic Activity of $\mathrm{MnO}$ in Melts Containing $\mathrm{SiO}_{2}, \mathrm{~B}_{2} \mathrm{O}_{3}$, and $\mathrm{TiO}_{2}$ by B. K. D. P. Rao and D. R. Gaskell

\title{
Page 472:
}

The sentence beginning on line 5 of column 2 should read:

In the present work it was found that the compounds $\mathrm{MnO} \cdot 2 \mathrm{~B}_{2} \mathrm{O}_{3}$ and $\mathrm{MnO} \cdot 3 \mathrm{~B}_{2} \mathrm{O}_{3}$ do not exist and that, instead, a wide liquid immiscibility gap exists between virtually pure $\mathrm{B}_{2} \mathrm{O}_{3}$ and the $\mathrm{MnO} \cdot \mathrm{B}_{2} \mathrm{O}_{3}$ composition. 